\title{
Flexible Acrylate Dentures versus Chromium Cobalt Removable Partial Dentures - a Viable Therapeutical Solution
}

\author{
DANA GABRIELA BOSINCEANU ${ }^{1}$, IOAN GABRIEL SANDU2,3, ELENA RALUCA BACIU1*, DAN NICOLAE BOSINCEANU1, \\ ZINOVIA SURLARI ${ }^{2 *}$, IOANA MARTU ${ }^{1 *}$, CARINA BALCOS ${ }^{1}$, MARIA BOLAT ${ }^{1}$ \\ ${ }^{1}$ Grigore T. Popa University of Medicine and Pharmacy lasi, 16 Universitatii Str., 700115 lasi, Romania \\ ${ }^{2}$ Gheorghe Asachi Technical University of lasi, Faculty of Material Science and Engineering, 61A D. Mangeron Blvd., 700050 lasi, \\ Romania \\ ${ }^{3}$ Romanian Inventors Forum, 3 Sf. Petru Movila, Str. BI. L11, Sc. A, Et. III, Ap.3, 700089 Iasi, Romania
}

\begin{abstract}
The aim of this study was to compare the evaluation of two groups of denture wearers following specific parameters at 6 and 12 month after the treatment. The study group included 15 patients with Cr-Co alloy skeletal dentures with metallic crowns with distal occlusal clasps and the base of methyl polymethacrylate (PMMA) and 15 with partially flexible dentures made of super-nylon polyamide resin. Based on the evaluation of these dentures, the 7 clinical parameters stated, over a period of 18 months and within the limits of this study, it can be concluded that partial removable dentures made of nylon-Valplast superpolyamide can be considered as a viable option to Cr-Co alloy.
\end{abstract}

Keywords: denture wearers, acrylic polymer, cobalt chromium, dentures

Poly(methyl methacrylate) (PMMA) has been a commonly used denture base biomaterial since 1937 The properties of favorable working characteristics, ease of manipulation, aesthetic appearance, stability in the oral environment, and accurate fit and polishability have contributed to the success of this material [1-4]. However, one drawback of the acrylic resin dentures is lack of toughness. Denture base biomaterials are subjected to many different types of stresses, including compressive, tensile, and shear stresses, and most fractures develop during function by the repeated masticatory forces. Extraorally, high-impact forces might occur as a result of accidental drop of the prosthesis $[5,6]$.

In the last few decades, edentation treatment has seen major changes for multiple causes, including increasing the level of dental medical education, introducing new techniques, methods and materials [7-9]. The partial denture remained over time and is still a difficult art to understand for dentists. The cobalt chromium ( $\mathrm{Cr}-\mathrm{Co}$ ) alloy has traditionally been used as the material of choice in the manufacture of skeletal dentures since 1929. Prosthetic substitute becomes a denture when it is applied and integrates into the system of the prosthetic field, accomplishing the morphological structure and functional reconstruction of an organ [10-12]. However, the use of metal alloys together with design considerations presents unique challenges both at aesthetic level and at the biological acceptance of restoration [13].

The recent improvement of nylon thermoplastic resins presents these as an alternative material that could overcome the challenges of skeletal dentures with metallic bases [14]. They have been introduced as a superpolyamide in which the resin polymers are armed with glass fillers in order to produce a material that is more stable in nature and provides resistance to aging of the polymer [15-18]. This material is claimed to have greater resistance to wear, flexibility, fatigue strength, dimensional stability, wear characteristics and solvent resistance. It also matches the color of the tooth and the color of the gingival tissue, has low weight and heat resistance [19-23]. There is a small number of papers in the literature on the efficacy of this material as a substitute for the chromium-cobalt alloy and it needs testing in different clinical situations to allow for universal acceptance [24].

Therefore, the present study pursued several clinical objectives as follows: dentures evaluation for 30 patients; comparison of specific parameters at 6 months and 12 months after treatment.

\section{Experimental part}

Materials and methods

The present paper is conducted on a group of patients aged 25-45 years of age, of a middle-income group, fit from general health point of view, with an average oral health status and no significant harmful habits. Patients were randomly selected for this study. These patients presented in the Faculty of Dental Medicine lasi during 2016-2017 for specialized prosthetic treatment.

The 30 patients were randomly assigned to two groups of 15 each, patients in group $A$ and group B.Group A received $\mathrm{Cr}$-Co alloy skeletal dentures with metallic crowns with distal occlusal clasps and the base of methyl polymethacrylate (PMMA) Patient Group B received partially flexible dentures made of super-nylon polyamide resin.

After the dentures insertion, their clinical performance was reviewed periodically over a year, after 6 months and then 12 months after the following parameters : esthetics , soft tissue tolerance, gingival health, periodontal health, dentures fractures and overall satisfaction. The patients responding to the questionnaire without omitting either a question, explaining where there were difficulties in understanding the question, not influencing the results obtained and responding to knowledge. If there were patients with the patient, the responsibility and the correctness of the response depended on them.

\section{Manufacturing and insertion of Cr-Co alloy skeletal dentures for patient group $A$}

All dentures were made of the same material. Following preliminary impression recorded with alginate, in standard metal or plastic trays, the preliminary casts were poured. On these were made the individual trays of each patient. 
Wherever it was, the abutment teeth were treated and received metal-ceramics or metal-composite crowns. On the duplicate cast were made the wax denture then the metallic base and spaces for the future metallic clasps.

The cast with wax denture with the mounted teeth was inserted into the sinks. Each tooth was mechanically prepared for retention and reintroduced into its place in the upper half of the cylindrical sink with cement (cement provided with the Valplast system which does not change colour at the injection heat nor does it permanently bind to the surface of the teeth like cyanoacrylates or other cementing agents). Then the sinks were injected with the recommended resin cartridge Valplast (Valplast, USA) and polymerized followed by cooling for thirty minutes. The dentures were then carefully recovered from sinks, finished, polished, rigorously washed in an ultrasound bath and delivered.

\section{Manufacturing and insertion of flexible partial dentures for patients in group $B$}

Materials and equipment used for the manufacture of flexible prostheses were from Valplast. Preliminary impressions were recorded using standard metallic trays and alginate. Preliminary casts were poured and obtained individual trays. Fluid silicone was used for second impression and functional casts were poured and then duplicated using reversible hydrocolloid.

\section{Results and discussions}

The results were synthesized in table 1 for group $A$ of skeletal denture wearers and in table 2 for group B of flexible partial dentures. The data reveal both the subjective assessment of the patients and the objective assessment made by the physician, according to the clinical examination and the indices mentioned in the material and method part.

The data obtained were entered in the SPSS 14.0 program and the Man Whitney test was used, the minimum and maximum values obtained, correlating the values then as can be seen in table 3 .
The statistical description indicates that the average for the first parameter (subjective aesthetic evaluation), with values of 1.67 for patients in group $B$, was close to the extremely satisfactory (value 2), compared to the corresponding values of 0.67 for the same parameter for patients in group $A$. The values for the third and fourth parameters (soft tissue oral tolerance, subjective and objective evaluation) were almostidentical for both groups with group A having values of 0.13 and 0.00 , respectively, and group $B$ having values of 0.20 and 0.00 respectively.

The consistent values of 0.00 for the five and six parameters (gingival and periodontal health) for both groups show that support tissues are clinically normalized in all thirty cases of patients. The sixth parameter (fracture frequency) for both groups recorded almost similar values between the two groups, being slightly higher for group $A$ (group A having an average of 0.80 while group $B$ averaging $0.67)$.

Seventh parameter, ie overall patient satisfaction, is clearly higher for patients in Group B, with a value of 1.77, compared to 1.47 for patients in Group A. Throughout the observation period for this study, Valplast prostheses showed similar biocompatibility to that of skeletal dentures.

The clinical parameter of dentures fracture frequency during use was more or less similar for both groups, with a slightly higher incidence for group A patients. This can be attributed to the more fragile and more rigid nature of the cobalt chromium alloy due to density its reduced modulus of elasticity compared to the $470 \mathrm{MPa}$ flexibility module at the super-polyamide body temperature, making ita virtually unbreakable material.

The clinical parameter of overall patient satisfaction also showed results for patients favoring Group B compared to those in Group A. This difference was clearly influenced by the apparent difference in the two types of dentures.

Valplast is a super polyamides belonging to the nylon family. Nylon is a resin derived from dicarboxylic acid, diamine, amino acids and lactone which can be used in the case of the aesthetic concern of the patient, as recommended by Singh et al (2013) [25].

Table 1

VALUES FOR A GROUP OF SHELETAL DENTURE WEARERS

\begin{tabular}{|l|l|l|l|l|l|l|l|l|}
\hline Case & Group & Esthetics & $\begin{array}{l}\text { Soft tissue } \\
\text { tolerance } \\
\text { subjective }\end{array}$ & $\begin{array}{l}\text { Soft tissue } \\
\text { tolerance } \\
\text { objective }\end{array}$ & $\begin{array}{l}\text { Gingiva } \\
\text { Health }\end{array}$ & $\begin{array}{l}\text { Periodontal } \\
\text { health }\end{array}$ & Fractures & $\begin{array}{l}\text { Overall } \\
\text { satisfaction }\end{array}$ \\
\hline 1 & $\mathrm{~A}$ & 1 & 0 & 0 & 0 & 0 & 0 & 1 \\
\hline 2 & $\mathrm{~A}$ & 1 & 0 & 0 & 0 & 0 & 1 & 1 \\
\hline 3 & $\mathrm{~A}$ & 0 & 1 & 0 & 0 & 0 & 1 & 1 \\
\hline 4 & $\mathrm{~A}$ & 1 & 0 & 0 & 0 & 0 & 1 & 2 \\
\hline 5 & $\mathrm{~A}$ & 0 & 0 & 0 & 0 & 0 & 0 & 1 \\
\hline 6 & $\mathrm{~A}$ & 1 & 0 & 0 & 0 & 0 & 1 & 2 \\
\hline 7 & $\mathrm{~A}$ & 1 & 0 & 0 & 0 & 0 & 1 & 2 \\
\hline 8 & $\mathrm{~A}$ & 0 & 1 & 0 & 0 & 0 & 1 & 1 \\
\hline 9 & $\mathrm{~A}$ & 1 & 0 & 0 & 0 & 0 & 1 & 2 \\
\hline 10 & $\mathrm{~A}$ & 0 & 0 & 0 & 0 & 0 & 1 & 1 \\
\hline 11 & $\mathrm{~A}$ & 1 & 0 & 0 & 0 & 0 & 1 & 2 \\
\hline 12 & $\mathrm{~A}$ & 1 & 0 & 0 & 0 & 0 & 1 & 2 \\
\hline 13 & $\mathrm{~A}$ & 0 & 0 & 0 & 0 & 0 & 0 & 1 \\
\hline 14 & $\mathrm{~A}$ & 1 & 0 & 0 & 0 & 0 & 1 & 1 \\
\hline 15 & $\mathrm{~A}$ & 1 & 0 & 0 & 0 & 0 & 1 & 2 \\
\hline
\end{tabular}


Table 2

VALUES FOR B GROUP OF FLEXIBLE DENTURE WEARERS

\begin{tabular}{|c|c|c|c|c|c|c|c|c|}
\hline Case & Group & Esthetics & $\begin{array}{l}\text { Soft tissue } \\
\text { tolerance } \\
\text { subjective }\end{array}$ & $\begin{array}{l}\text { Soft tissue } \\
\text { tolerance } \\
\text { objective }\end{array}$ & $\begin{array}{l}\text { Gingiva } \\
\text { health }\end{array}$ & $\begin{array}{l}\text { Periodontal } \\
\text { health }\end{array}$ & Fractures & $\begin{array}{l}\text { Overall } \\
\text { satisfaction }\end{array}$ \\
\hline 1 & $\mathrm{~B}$ & 2 & 1 & 0 & 0 & 0 & 1 & 2 \\
\hline 2 & $\mathrm{~B}$ & 2 & 1 & 0 & 0 & 0 & 1 & 2 \\
\hline 3 & B & 2 & 0 & 0 & 0 & 0 & 1 & 2 \\
\hline 4 & $B$ & 1 & 0 & 0 & 0 & 0 & 1 & 1 \\
\hline 5 & $\mathrm{~B}$ & 1 & 1 & 0 & 0 & 0 & 1 & 2 \\
\hline 6 & B & 1 & 0 & 0 & 0 & 0 & 1 & 1 \\
\hline 7 & $\mathrm{~B}$ & 2 & 0 & 0 & 0 & 0 & 1 & 2 \\
\hline 8 & $B$ & 2 & 1 & 0 & 0 & 0 & 0 & 2 \\
\hline 9 & B & 2 & 0 & 0 & 0 & 0 & 0 & 2 \\
\hline 10 & $\mathrm{~B}$ & 2 & 0 & 0 & 0 & 0 & 1 & 2 \\
\hline 11 & $\mathrm{~B}$ & 2 & 0 & 0 & 0 & 0 & 1 & 3 \\
\hline 12 & B & 2 & 0 & 0 & 0 & 0 & 1 & 3 \\
\hline 13 & $\mathrm{~B}$ & 1 & 0 & 0 & 0 & 0 & 0 & 2 \\
\hline 14 & B & 1 & 0 & 0 & 0 & 0 & 0 & 2 \\
\hline 15 & $\mathrm{~B}$ & 2 & 0 & 0 & 0 & 0 & 0 & 3 \\
\hline
\end{tabular}

Table 3

STATISTIC COMPARATIVE VALUES BETWEEN GROUP A AND B

\begin{tabular}{|c|c|c|c|c|c|c|c|c|}
\hline Denture & & Esthetics & $\begin{array}{l}\text { Soft tissue } \\
\text { tolerance } \\
\text { subjective }\end{array}$ & $\begin{array}{l}\text { Soft tissue } \\
\text { tolerance } \\
\text { objective }\end{array}$ & $\begin{array}{l}\text { Gingiva } \\
\text { health }\end{array}$ & $\begin{array}{l}\text { Periodontal } \\
\text { health }\end{array}$ & Fractures & $\begin{array}{l}\text { Overall } \\
\text { satisfaction }\end{array}$ \\
\hline \multirow{5}{*}{ B } & Median & 1.67 & 0.27 & 0 & 0 & 0 & 0.67 & 2.07 \\
\hline & $\mathrm{N}$ & 15 & 15 & 15 & 15 & 15 & 15 & 15 \\
\hline & Dev std & 0.488 & 0.458 & 0 & 0 & 0 & 0.488 & 0.594 \\
\hline & Min & 1 & 0 & 0 & 0 & 0 & 0 & 1 \\
\hline & Max & 2 & 1 & 0 & 0 & 0 & 1 & 3 \\
\hline \multirow{5}{*}{ A } & Median & 0.67 & 0.13 & 0 & 0 & 0 & 0.8 & 1.47 \\
\hline & $\mathrm{N}$ & 15 & 15 & 15 & 15 & 15 & 15 & 15 \\
\hline & Dev std & 0.488 & 0.352 & 0 & 0 & 0 & 0.414 & 0.516 \\
\hline & Min & 0 & 0 & 0 & 0 & 0 & 0 & 1 \\
\hline & Max & 1 & 1 & 0 & 0 & 0 & 1 & 2 \\
\hline
\end{tabular}

\section{Conclusions}

Based on the evaluation of these dentures, the 7 clinical parameters stated, over a period of 18 months and within the limits of this study, it can be concluded that partial removable dentures made of nylon-Valplast superpolyamide can be considered as a viable option to $\mathrm{Cr}$-Co alloy. The main advantage of nylon partial dentures is the absence of a metal frame, offering improved aesthetics. In addition, polyamide dentures bases are considered to offer some benefits to patients who are allergic to methyl polymethacrylate (PMMA).

Unfortunately, the lack of a traditional metallic base reduces the rigidity and support of occlusal clasps as reported by Hamanaka etal (2011) [26]. Another negative aspect of the use of polyamide resin base is surface roughness and polishing difficulties that lead to bacterial and fungal colonization on its surface as reported by Ito (2013).

On the other hand, the technopolymer materials, such as thermoelastic resins (Versacryl), have viscoelastic properties. They are prepared to have a higher flexibility, which is approximately ten times larger than the metal clasps and return to their predefined dimensions after they have been deformed.

Aknowledgement: This work was supported by a grant of the Romanian Ministery of Research and Innovation, CCCDI -UEFISCDI, project number PN-III-P1-1.2-PCCDI-2017-0239/60PCCDI 2018, within PNCDI III

\section{References}

1. LOVELL, L.G., BERCHTOLD, K.A., ELLIOT, J.E., LU, H., BOW MAN, C.N., Polymers for Advanced Technologies, 12, 2001, p. 335.

2. BOSINCEANU, D.N., BOSINCEANU, D.G., BOLAT, M., BACIU, R., FORNA, N.C., Rom. J. Oral Rehab., 8, no. 1, 2016, p. 7.

3. CARAIANE, A., RAFTU, G., SIN, E.C., BUSTIUC, S.G., Rev. Chim. (Bucharest), 69, no. 3, 2018, p. 725.

4. BOSINCEANU, D.N., SANDU, I.G., BOSINCEANU, D.G., FORNA, N.C., Rev. Chim. (Bucharest), 65, no. 4, 2014, p. 466.

5. EARAR, K., BICA, C., CERGHIZAN, D., ILIE, M., Mat. Plast., 53, no. 3, 2016, p. 512.

6. EARAR, K., CERGHIZAN, D., SANDU, A.V., MATEI, M.N., LEATA, R., SANDU, I.G., BEJ INARIU, C., COMAN, M., Mat. Plast., 52, no. 4, 2015, p. 487.

7. EARAR, K., MATEI, M.N., SANDU, A.V., HRISTIAN, L., BEJ INARIU, C., SANDU, I.G., Mat. Plast., 52, no. 1, 2015, p. 98.

8. DIACONU POPA, D., VITALARIU, A., TATARCIUC, M., MUNTEANU,

F., Rev. Chim. (Bucharest), 67, no. 8, 2016, p. 1571.

9. PODARIU, A.C., BORTUN, C.M., POPOVICI, A.R., OANCEA, R., ROSIANU, R.S., Rev. Chim. (Bucharest), 63, no. 8, 2012, p. 809.

10. BORTUN, C.M., CERNESCU, A., ARDELEAN, L., Mat. Plast., 49, no. 1, 2012, p. SAQ5.

11. BOSINCEANU, D.G., SANDU, I.G., BOSINCEANU, D.N., MARTU, I., SURLARI, Z., FORNA, N.C. Mat. Plast., 55, no. 3, 2018, p. 423.

12. MARTU, I., BOSINCEANU, D.G., FORNA, N.C., VITALARIU, M.A., LUCHIAN, I., BOSINCEANU, D.N., Rom. J. Oral Rehab., 9, no. 2, 2017, p. 60.

13. POPA, CG., LUCHIAN, I., IOANID, N., GORIUC, A., MARTU, I., BOSINCEANU, D., MARTU, MA., TIRCA, T., MARTU, S., Rev. Chim. (Bucharest), 69, no. 6, 2018, p. 1578. 
14. MARTU, S., NICOLAICIUC, O., SOLOMON, S., Rev Chim (Bucharest), 68, no. 5, 2017, p. 1946.

15. SOLOMON, S.M., PASARIN, L., URSARESCU, I., MARTU, I., BOGDAN, M., NICOLAICIUC, O., IOANID, N., MARTU , S., Int. J. Exp. Med., 9, no. 2, 2016, p. 4411.

16. MARTU, I., GORIUC, A., MARTU, M.A., VATA, I., BACIU, R., MOCANU, R., SURDU, A.E., POPA, C., LUCHIAN, I., Rev. Chim. (Bucharest), 68, no. 10, 2018, p. 2407.

17. SANDU, A.V., CODDET, C., BEJ INARIU, C., Rev Chim (Bucharest), 64, 2012, p. 401.

18. HRIB, C.G., SANDU, I., EARAR, K., BIRSA, L.M., Rev. Chim. (Bucharest), 65, no. 12, 2014, p. 1453.

19. CRISTACHE, C.M., OANCEA, L., DIDILESCU, A.C., BURLIBASA, M., TOTU, E.E., Rev. Chim. (Bucharest), 69, no. 2, 2018, p. 463.
20. BOLAT, M., BOSINCEANU, D.N., BACIU, E.R., FORNA AGOP, D., BOSINCEANU, D.G., FORNA, N.C., Rom. J. Oral Rehab., 9, no. 4, 2017, p.93.

21. TOTU, E.E., CRISTACHE, C.M., Rev. Chim. (Bucharest), 68, no. 9, 2017, p. 2102.

22. MANEA, L.R., BERTEA, A., NECHITA, E., POPESCU, C.V., SANDU, I., Rev. Chim. (Bucharest), 67, no. 8, 2016, p. 1607.

23. MANEA, L.R., BERTEA, A., NECHITA, E., POPESCU, C.V., SANDU, I., Rev. Chim. (Bucharest), 67, no. 7, 2016, p. 1284.

24. POPESCU, V., SANDU, I.C.A., POPESCU, G., Rev. Chim. (Bucharest), 67, no. 1, 2016, p. 74.

25. SINGH, K., AERAN, H., KUMAR, N., GUPTA, N., J. Clin. Diagn. Res., 7, no. 10, 2013, p. 2372.

26. HAMANAKAI, TAKAHASHI Y, SHIMIZU H., Acta Odontol. Scand., 69, no. 2, 2011, p. 75.

$\overline{\text { Manuscript received: } 13.12 .2018}$ 